\title{
Konaklama İşletmelerinde Kurumsallaşmanın Örgütsel Yenilik Açısından Stratejik Rolü
}

\section{The Strategic Role of Institutionalization for Accommodation Enterprises in Terms Of Organizational Innovation}

\author{
Aziz Gökhan ÖZKOÇ* \\ Ebru KEMER ${ }^{* *}$
}

\begin{abstract}
Özet
$\mathrm{Bu}$ çalışma ile konaklama işletmelerinde üst yönetimlerin örgütsel yenilik yönelimlerine etki eden kurumsallaşma unsurlarının belirlenmesi amaçlanmıștır. Araştırma kapsamında nicel veri elde etmek amacıyla oluşturulan anket formu, Nevşehir İli’nde faaliyet gösteren 3,4 ve 5 yıldızl konaklama işletmelerinde görev yapan üst düzey yöneticilere uygulanmıştır. Yapılan korelasyon ve regresyon analizleri sonucu elde edilen sayısal veriler incelendiğinde; örgütsel yenilik ile kurumsallaşma unsurları arasında pozitif yönlü ilişkiler saptanmış olup, örgütsel yeniliğin açıklanmasında kurumsallaşmayı oluşturan unsurlardan nesnellik ve tarafsızlık ile şeffaflık boyutlarının herhangi bir anlamlı etkisi belirlenemezken, formalleşme ve profesyonelleşme boyutunun yüksek düzeyde pozitif yönlü anlamlı etkisi tespit edilmiştir. Sonuç olarak üst yönetimlerin, örgütsel yenilik hedeflerini gerçekleşmeden önce, formalleşmiş ve profesyonel bir kurumsal çerçeve dahilinde hareket etmeleri gerektiği önerilmektedir.
\end{abstract}

Anahtar Kelimeler: Kurumsallaşma, Örgütsel Yenilik, Konaklama İşletmeleri

\begin{abstract}
The objective of this study is to determine the factors for institutionalization that affect approaches of organizational innovation for upper methods in the accommodation enterprises. A questionare form which is designed to obtain statistical data in context with the research has been conducted on the higher rank of managers on duty who work at accomodation enterprises with 3,4 or 5 stars of quality, in the province of Nevşehir, Turkey. After the numerical data that was obtained in the end of correlational and regressional analyses was studied, it was found that there are positive relations between organisational innovation and institutionalization factors. Additionally, as for the description of the factors that constitute the institutionalization for organisational innovation, there was no any meaningful effect found by parameters of objectivity and neutrality, and transparency. However, as for the parameter of formallization and professionalization, a highly positive and meaningful effect was determined. As a result, it is proposed that higher managements of enterprises should have a frame of action with a formally-established and professional perspective before realizing their organisational innovation objectives.
\end{abstract}

Key Words: Institutionalization, Organisational Innovation, Accommodation Enterprises

\section{Giriş}

Örgütlere rekabet üstünlüğü kazandıran stratejik hamlelerin ve yeniliklerin belirli bir kurumsal disiplin çerçevesinde tasarlanması ve uygulanmasıyla, örgütsel etkinliğin ve verimliliğin artabileceğine dair yönetim yazınında önemli teorik bulgulara rastlanmaktadır. Benzer biçimde, kurumsallaşmaya dönük uygulamalar sayesinde örgütlerin, iç ve dış çevreleriyle uyum içinde çalışabilme konusunda da önemli adımlar atabileceği öngörülmektedir. Bilgin'e (2007) göre, kurumsallaşma düzeyi yüksek olan örgütler çevresel koşullara uyum sağladıktan sonra yapılarını sabitleyerek kurumda belirlenmiş misyon, vizyon, amaç, kural ve değerler ile çevrelerini etkilemeye başlayacaklardır. Kurumsallaşma ise, genel olarak işletmenin diş çevresiyle etkileşimi sonucu ortaya çıkan uyumlu ve kontrollü faaliyetler sistematiği ve bu sistematiğin sonucunda meydana gelen kuralların ve prosedürlerin hayata geçirilmesi olarak tanımlanmaktadır (Meyer ve Rowan, 1997, s. 343).

\footnotetext{
* Yrd. Doç. Dr., Nevşehir Hacı Bektaş Veli Üniversitesi, Turizm Fakültesi, azizgozkoc@nevsehir.edu.tr ** Öğr. Gör., Kapadokya MYO, kemer_ebr@hotmail.com
}

Özkoç, A , Kemer, E . (2017). The Strategic Role of Institutionalization for Accommodation Enterprises in Terms of Organizatıonal Innovation. Gaziantep University Journal of Social Sciences, 16 (2), 568-578. DOI: 10.21547/jss.296231 
Açık sistemler olarak örgütler, çevreleriyle sürekli etkileşim halinde olan ve her yönüyle kontrol edemediği bir diş çevrede faaliyet gösteren sistemlerdir. Dolayısıyla tüm karar ve uygulamalarında çevredeki değişimi ve yeniliği göz önünde bulundurmak zorundadırlar. Örgütlerin çevrelerinde meydana gelen gelişmeleri sistematik şekilde izleyerek bilgi üretmesi ve kendisini çevrenin beklentisi yönünde davranmaya zorlaması (Avc1, 2009, s. 122) yenilikleri bir süreç olarak benimsediklerini ve yenilikler sayesinde pazarda meşrulaşmaya çalıştıklarını göstermektedir (Westphal vd., 1997, s. 373). Emek yoğun bir sektör olarak, turizm sektörü içinde faaliyet gösteren konaklama işletmelerinin de benzer biçimde varlığını sürdürebilmeleri, hizmet kalitesini arttırabilmeleri ve rekabet edebilmeleri devamlılıklarını sağlamalarına bağlıdır.

$\mathrm{Bu}$ çalışma; "konaklama işletmelerinin yeniliklere açık olmalarında ve değişen çevre koşullarına uyum göstermelerinde kurumsallaşma stratejik bir unsur olarak değerlendirilebilir mi?" veya "kurumsallaşma eğilimleri birçok örgüt içi unsurla birlikte yeniliğin de örgüt içinde sistematikleşmesini ve eş biçimli hale dönüşmesini sağlayabilir mi?" sorularına nitel ve nicel veriler ışı ğında yanıt aramaktadır. Bu araştırma, teorik ve ampirik olarak Türkiye'de kurumsallaşma ile yenilik etkileşimine turizm sektörü çerçevesinde değinen ilk çalışma olacaktır. Elde edilen bulguların, konaklama işletmeleri yöneticilerine, kurumsallaşmaya yönelik kararlarının örgütsel yenilik açısından ne düzeyde stratejik önem arz ettiğini göstermesi hedeflenmiştir.

\section{Literatür Taraması}

\section{Kurumsallaşma Kavramı ve Unsurları}

Örgütlerde kurumsallaşma yaklaşımının incelenmesi 1930'lu yılların sonunda başlamış olup (Tavşanc1, 2009), ABD ve Japonya gibi devletler bu yaklaşımla 1980'lerde ilgilenirken, Türkiye'de 1990'lı y1llarda incelenmeye başlanmıştır (Ak, 2010). Örgütsel kurumsallaşma yaklaşımı eski kurumsallaşma yaklașımı ve yeni kurumsallaşma yaklașımı olarak iki kısımda incelenmektedir (Tavşanc1, 2009). Eski kurumsal yaklaşım çalışmalarının öncüsü Phillipe Selznick, 1949 yılında yayınlanan "TVA and Grassroots"' isimli çalışmasında dışsal tehditler karşısında bir örgütün zaman içinde nasıl yapısal değişimlere uğradığına ve biçimlendiğine değinmiştir (Aksoy, 2007, s. 13). Selznick (1996), bir örgütün faaliyet gösterdiği çevrede özel bir kimlik kazanması ve ayırıcı bir yetkinliği eğitimle ya da kendi kapasitesiyle kazanması sürecini kurumsallaşma olarak açıklamaktadır.

Yeni kurumsal yaklaşım ise, bilişsel yapılar üzerinde daha fazla duran, kültürel inanç sistemlerini ve çevresel faktörleri daha fazla inceleyen (Scott, 1995) ve örgütsel alanda meydana gelen yeni kavramları da ele alan bir yaklaşımdır (Boons ve Strannegard, 2000; Bozbayındır, 2014). Yeni Kurumsal Yaklaşım, yapıların belirli bir alanda örgütler arasında nasıl tekrar ettiğini meşruluk zorunluluğu için yapılan baskının bir sonucu olarak ortaya çıkan izomorfizm (eş biçimlilik) kavramı aracılığıyla açıklamaktadır (Bennett ve Thompson, 2011, s. 830).

İzomorfizm (eş biçimlilik) örgütlerin, yapı, strateji, kaynaklar ve baskılar bakımından diğer örgütleri taklit ettiği varsayımıyla başlar. Örgütler, dış çevrede aynı çevresel kaynaklara ihtiyaç duymakta ve bu nedenle de benzer baskılardan etkilenmektedir. Sosyal çevredeki kurumların kural ve yasaları örgütsel yapının şekillenmesinde etkilidir. Bundan dolayı örgütlerin birbirine benzemesi olarak adlandırılan izomorfizm ortaya çıkmaktadır. Kurumsal eş biçimlilik; örgütün sürekliliğini sağlamakta ve başarısını desteklemektedir (Kostova vd., 2008: 998). Yeni kurumsal yaklaşım ile birlikte kurumsallaşma, örgütün diş çevresiyle etkileşimi sonucu ortaya çıkan uyumlu ve kontrollü faaliyetler sistematiği ve bu sistematiğin sonucunda meydana gelen kuralların ve prosedürlerin faaliyete geçirilmesi olarak tanımlanmıştır (Meyer ve Rowan, 1997, s. 344). 
Kurumsallașmayı olușturan unsurlar formalleșme, profesyonellik, hesap verebilirlik, örgüt kültürü oluşturma ve tutarlılıktır. Bu boyutlar işletmelerde kurumsallaşma adına yapılması gerekenlerin belli bir düzene göre yapılmasını sağlayacak ve yöneticilerin nerelerde eksik kaldıklarını göstermeye yardım edecektir (Meşe, 2005).

Formalleşme, örgüt eylemlerinin kurallar, standartlar ve sistematik prosedürlerle belirlenerek örgüt içindeki değişik fonksiyonların koordinasyonunu sağlayacak şekilde örgüt yapılarının dizayn edilmesi ve yönetimsel fonksiyonların kim tarafından ve nasıl yürütüleceğinin belirlenmesi ve bunların yazılı hale getirilmesi olarak tanımlanmaktadır (Wallece 1995: 230). Formalleşen örgütlerin eylemlerinde belirlilik bulunmaktadır. Bu da başka kurumlarca aranan ve arzulanan bir durumdur. Diğer örgütler bu özelliklere sahip işletmelerle iş yapmayı tercih etmektedirler. Bunun sonucu olarak da işletmelerin müşteri yelpazesi gelişir ve kaynaklarında artış ortaya çıkar. Formalleşme pazarlama taktiklerinin de kurumsallaşmasını sağlamaktadır. Prosedürlere ve kurallara bağlanan taktiksel uygulamalar çalışanlarca daha iyi kavranır ve uygulanır ve süreklilik kazanır. Formalleşme, belirsizliği ve rol çatışmalarını azaltmaktadır (Kimberly, 1979, s. 437).

Günümüzde şirket kurabilmek için yasalarla belirlenmiş birçok prosedür vardır. $\mathrm{Bu}$ prosedürler kurumsallaşmanın ilk adımıdır. Bir şirketin kurumsallaşabilmesi için aslında kağıt üzerinde atılan bu adım dışında, atılması gereken ilk adım profesyonel yöneticilere güvenmektir (Aşan, 2010: 20). Örgütlerin profesyonelleşmesini sağlayan diğer adım istihdam edilen profesyonellerin örgütteki çalışanlar arasındaki oranıdır. Profesyonel çalışan sayısı arttıkça örgütler daha çok profesyonel özellik kazanmaktadırlar. Örgüt üyeleri tarafından profesyonelliğin yüksek olarak algılanması, örgütsel adaletin yüksek algılanmasını sağlamaktadır. Bu da çalıșanların örgüte olan bağlılığını ve katkılarını artırmaktadır. Yönetim fonksiyonlarından biri de kontroldür ve profesyonellik yönetimsel kontrolü kolaylaştırmaktadır (Scott 1987).

Örgütler, özellikle paydaşlarından gelen baskılar nedeniyle hesap verebilir olmaya zorlanmaktadır. Şeffaflık kavramıyla ifade edilen hesap verilebilirlik kavramı, işletmenin finansal performansı, kurumsal yönetimi, hissedarlık yapısı, iş ve faaliyetleri hakkında yeterli ve doğru bilginin zamanında açıklanmasıdır. Başka bir ifade ile yönetime ilişkin kural ve sorumlulukların açık şekilde tanımlanması, işletme yönetimi ve hissedar menfaatlerinin yönetim kurulu tarafından gözetilmesini ifade eder (Kiracı ve Alkara, 2009, s. 175).

Kültürel güç, örgüt kültürünün kabullenilme düzeyi ve örgüt içinde yaygın olarak paylaşılmasıdır. Kültürü oluşturan normlar, etik kurallar, değer ve ilkelerin örgüt üyelerince kabullenilme düzeyi arttıkça ve bütün üyelerce paylaşıldıkça güçlü bir kültür oluşmaktadır (Apaydın, 2008, s. 124). Tutarlılık ise, işletmelerin verdiği sözü tutması, misyon, strateji ve eylemler arasındaki uyum, aynı sektördeki benzer işi yapan işletmelere benzeme ve benzer durumlarda benzer tepkileri verme olarak tanımlanabilir. İşletmelerin kurumsallaşabilmeleri için tutarlı eylemler sergilemeleri ve kararlar almaları gerekmektedir (Apaydın, 2008, s. 125).

\section{Kurumsallaşma ve Örgütsel Yenilik İlişkisi}

İşletmelerin rekabetçi üstünlük elde edebilmesi için kendilerini tamamen farklı bir biçimde yeniden tanımlaması, farklı stratejiler yaratması yani rakiplerinden farklı olması ürün ve hizmetlerinde fark yaratabilmesi gerekir (Aktan, 2004, s. 118). Dolayısıyla işletmelerin tüm iş alanlarında yeniliğe ihtiyacı vardır (Elçi, 2007). Ekonomik büyümenin, artan istihdamın ve yaşam kalitesinin anahtarı olan yenilik günümüzde, sadece hiç olmayan bir ürünü ortaya çıkarmak değil aynı zamanda, süreç geliştirmek, farklılık yaratmak ve örgütsel anlamda farklı şeyler ortaya koymak olarak algılanmaktadır (Avermaete vd., 2003, s. 10). Bu bağlamda, yenilik hem bir süreç hem de bir sonuçtur. Yeni ürün üretmek için yapılan faaliyetler ve örgütsel 
değişim süreç yeniliğidir. Yenilik faaliyetleri sonucunda elde edilen yeni veya iyileşmiş mal ve hizmetler ise yeniliğin sonuç anlamını ifade eder (Schermerhon, 2007, s. 333).

İşletme alanında yeniliği konu alan çalışmalar incelendiğinde, genel olarak ürün yenilikleri, süreç yenilikleri, pazarlama yenilikleri ve örgütsel yenilik gibi konular üzerinde önemle durulduğu görülmektedir (Damanpour, 1991; OECD, 2006; Schermerhon, 2007; Sabuncu, 2014). Bu konulardan biri olarak örgütsel yenilik, teknoloji ve çevredeki değişikliklere uyum, öğrenme süreçleri ve örgütsel yapıların rolü üzerine odaklanan işletmelerin faaliyetlerinde ve çevreyle olan ilişkilerinde yeni bir işletme yönteminin uygulanması şeklinde ifade edilmektedir (Elçi, 2009).

OECD tarafından hazırlanan Oslo Kılavuzu (2006) örgütsel yeniliği üç şekilde tanımlamaktadır. Buna göre örgütsel yenilik;

- Örgütsel yapının önemli ölçüde değiştirilmesi,

- İleri yönetim tekniklerinin uygulanmas1,

- Yeni ya da tamamen değiştirilmiş stratejilerin uygulanmasıdır.

Kurumsallaşma dinamik bir süreçtir. Dolayısıyla değişen çevre koşulları sürekli incelenerek işletme hedeflerinin, işletme yapısının, işgören niteliklerinin, teknolojisinin ve iş görme yöntem ve biçimlerinin bu değiş̧ime adapte edilmesini gerektirir. (Karpuzoğlu, 2001).

Kurumsallaşma, örgütlerin faaliyet gösterdikleri çevreyle uyum sürecini ve bu kuruluşlarda zamanla oluşan ilerlemeleri açıklamaktadır. Bu ilerlemelerin sürekli hale gelmesi için, yönetim ve kontrol sistemlerinin yenilikçi uygulamalarla desteklenmesi önemlidir. Kurumsallaşma örgütsel süreçlere kısıtlama getirse dahi ancak yenilik ile başarıyı sağlayabilir (Gökçe, 2010). Dolayısıyla kurumsallaşma eğilimi ile desteklenmiş yenilikçi anlayışın üst yönetimler tarafından benimsenmesi ve örgüt içinde uygulanması önemlidir. Örneğin, kurumsallaşmayı açıklayan unsurlardan biri olan profesyonelleşme, işletmelerin yenilik yapmasını ve uyum sağlamasını arttırmaktadır (Ruekert vd., 1985). Benzer biçimde tutarlılık gösteren ve hesap verebilir niteliğe sahip örgütlerde yenilik ve uyum performansının arttığını ortaya koyan çalışmalar mevcuttur (Apaydın, 2008).

Peters ve Waterman (1982)' e göre yenilik çevredeki değişime karşı cevap verme becerisi ve yeni ürün geliştirme faaliyettir. Örgütsel yenilik ise örgütün bütün faaliyetlerinde ve her alanında yeni fikir ve davranışların benimsenmesi olarak tanımlanmaktadır (Damanpour, 1991, s. 157). Kurumsallaşma örgütlerin yenilikçi yönelimlerine etki ederek onların performanslarını etkiler (Yılmaz, 2007). Damanpour (1991)'a göre yeniliğin benimsenmesi genel olarak, benimseyen örgütün verimliliği ya da performansına katkıda bulunmasını amaçlayan planlı bir süreçtir. Dolayısıyla, örgüt yeni fikir ve davranışları ya kendisi geliştirmesi ya da satın alması gerekmektedir. Her iki durumda da yeniliklerin benimsenmesi, örgütün performans ve etkinliğine olumlu katkılar yapacaktır. Ayrıca yenilik işletmenin tamamından toplanacak olan fikirlerin sistemli bir şekilde geliştirilmesini yani kurumsallaşmasını sağlamaktadır (Baltalar, 2012). Yani bir taraftan örgütlerin kurumsallaşma eğilimlerinin yenilikçiliği destekler nitelikte olması gerekirken, diğer taraftan yenilikçiliğin örgüt içinde işlevsel hale gelebilmesi için kurumsallaşmaya ihtiyaç vardır.

Bir örgütte yeniliği destekleyen yön veren üst yönetimin inanç, değer, vizyon ve özellikleridir. Yeniliği destekleyen yöneticiler, yenilikçi fikirlere gerekli kaynak ve uzmanlığı sağlama, çalışanlara destek verme, motivasyonlarını arttırma, iletişim kurma, güçlendirme, performans değerlendirme, açık kapı politikası uygulama, yenilikçi düşünce ve faaliyetleri kurumsallaştırma gibi faaliyetlere odaklanır (Warner ve Pyle, 1998, s. 21; Antoncic ve Hisrich, 2001, s. 501-502). Tüm bu faaliyetleri de ancak profesyonel bir anlayışla hareket eden 
yöneticilerin başarabileceği göz ardı edilemez bir gerçektir. Ayrıca yenilik müşteri memnuniyetini sağlayan müşteri sadakatini arttıran çalışanlara yön veren bir unsurdur. İşletmelerin açık bir sistem olması sebebiyle çevreye ve zamana uyum sağlaması gerekmektedir. Yenilikçi olmayan örgütlerin hayatta kalma gücü ve gelişmeleri eksik olacaktır (Gökçe, 2010, s. 4). Örgütler artık kurumsal stratejilerini şekillendirirken dahi yenilik faktörünü ön planda tutmakta ve kurumsallaşma stratejilerine yeniliği ayrılmaz unsur olarak ilave etmektedir (Keskin, 2006, s. 401). Örgütsel yenilik mevcut düzende işletmeler için bir zorunluluk halini almış ve kurumsal kimliğin önemli bir parçası olarak görülmüştür (Altun, 2008). Oluşturulan teorik çerçeve baz alınarak, bu çalışma kapsamında geliştirilen araştırma hipotezi ve buna bağlı alt hipotezler şu şekildedir:

$\mathbf{H}_{1}$ : Konaklama işlemelerinin kurumsallaşma eğilimleri, örgütsel yenilik yönelimlerini pozitif yönde etkiler.

$\mathbf{H}_{1(1)}$ : Konaklama işlemelerinin nesnellik ve tarafsızlık yönündeki kurumsallaşma eğilimleri, örgütsel yenilik yönelimlerini pozitif yönde etkiler.

$\mathbf{H}_{1(2)}$ : Konaklama işletmelerinin şeffaflık yönündeki kurumsallaşma eğilimleri örgütsel yenilik yönelimlerini pozitif yönde etkiler.

$\mathbf{H}_{1(3)}$ : Konaklama işletmelerinin formalleşme ve profesyonelleşme yönündeki kurumsallaşma eğilimleri, örgütsel yenilik yönelimlerini pozitif yönde etkiler.

\section{Yöntem}

\section{Örneklem Seçimi ve Prosedür}

Konaklama işletmelerinde kurumsallaşma eğilimi ile desteklenmiş yenilikçi yönelimlerin varlığını sorgulamak yönünde geliştirilen araştırma hipotezlerini test etmek amacıyla, bu çalışma kapsamında bir anket formu oluşturulmuş ve anket çalışması sonucu elde edilen veriler değerlendirilmiştir.

Anket çalışması, Türkiye'nin kültür turizmi başkenti olarak bilinen Kapadokya Bölgesi'ne bağlı Nevşehir İli'nde faaliyet gösteren 3, 4 ve 5 yıldızlı konaklama işletmelerinde görev yapan genel müdür ve departman müdürleriyle birebir görüşülerek uygulanmıştır. Anket formunun iletilmesi yönünde, e-posta ve telefon aracılığıla iletişim kurulan yöneticilerden bir kısmı, çeşitli nedenlerle araştırmaya dahil olmak istememişlerdir. $\mathrm{Bu}$ durum örneklem hacminin küçülmesine yol açmıştır. Türkiye Cumhuriyeti Kültür ve Turizm Bakanlığı'nı 2015 yılı verilerine göre Nevşehir İli'nde toplam 27 adet 3, 4 ve 5 yıldızlı konaklama işletmesi faaliyet göstermektedir. Bölge'de faaliyet gösteren 9 konaklama işletmesi anket çalışmasına katılmamış olup, geri kalan 18 işletmede görev yapan yöneticilerle anket çalışması gerçekleştirilmiştir.

Araştırmada örnekleme tekniği olarak ise "kolayda örnekleme" tekniği uygulanmıştır. Bu teknikte esas, ankete cevap veren herkesin örneğe dahil edilmesidir. En kolay bulunan denek en ideal olanıdır. Denek bulma işlemi arzu edilen örnek büyüklüğüne ulaşılana kadar devam eder (Altunışık vd., 2007). Araştırma verileri, 2016 yılı Nisan ayında toplanmış ve konaklama işletmelerinde görev yapan toplam 81 üst düzey yöneticiden sağlıklı bir geri bildirim alınmıştır. Araştırmaya dahil edilen örneklem kütlesi, mekânsal kısıtlılıklar ile zaman ve maliyet kısıtlılığ nedeniyle genişletilememiştir.

Araştırmaya katılan 81 yöneticinin 19'u (\%23,5) 3 yıldızlı, 42'si (\%51,9) 4 yıldızlı ve 20 'si $(\% 24,6)$ ise 5 yıldızlı konaklama işletmelerinde görev yapmaktadır. Yöneticilerin demografik özelliklerine bakıldığında, 67 yöneticinin (\%83) erkek, 14 (\%17) yöneticinin ise kadın olduğu görülmektedir. Katılımcıların yaşları ise ağırlıklı olarak, 31-50 (n=64; \%79) yaş aralığındadır. Yöneticilerin eğitim durumlarına bakıldığında ise, önlisans $(n=22 ; \% 27,2)$ ve 
lisans $(\mathrm{n}=29 ; \% 35,8)$ eğitimi almış yöneticilerin ağırlıkta bir orana sahip olduğu göze çarpmaktadır. Tüm bu rakamların yanı sıra, anket çalışmasına katılan yöneticilerin, önemli bir çoğunluğu (lise, önlisans veya lisans düzeyinde) turizm eğitimi aldıklarını belirtmiştir ( $\mathrm{n}=62$; \%76,5). Yöneticilerin sektörde ve görev yaptıkları işletmelerde çalışma süreleri ise 1 ile 10 yıl aralığında değişmektedir.

\section{Kullanılan Ölçekler ve Güvenilirlik Analizi}

Araştırmada veri toplama aracı olarak belirlenen ölçeklerin tümü orijinal dili İngilizce olan ve Türkiye'de yapılan çeşitli çalışmalarda Türkçe'ye çevrilmiş ölçeklerdir. Ölçekteki ifadelerin tümü 5'li Likert Ölçeği (1-Kesinlikle Katılmıyorum ..... 5- Kesinlikle Katılıyorum) şeklinde tasarlanmıştır.

Kurumsallaşma Ölçeği: Konaklama işletmelerinin kurumsallaşma eğilimlerini ölçmek amacıyla, Alpay vd. (2008) tarafından geliştirilmiş ölçekten yararlanılmıştır. Bu ölçek, ilgili yazın tarandıktan sonra geliştirilmiş olan diğer ölçekler arasından ifadelerinin turizm sektöründeki işletmelere daha uygun olması nedeniyle tercih edilmiştir. Kurumsallaşma ölçeği; nesnellik ve tarafsızlık ( 6 ifade), şeffaflık (4 ifade) ve formalleşme/profesyonellik (8 ifade) olmak üzere üç boyutta toplam 18 ifadeden oluşmaktadır (Örnek İfade: Herkesin bildiği orta ve uzun dönemli planlarımız bulunmaktadır). Ölçeğin güvenilirlik katsayısı Alpha=0,88 olarak belirlenmiştir. Güvenilirlik katsayısının (Cronbach's Alpha) 0.70 ve üstü olduğu durumlarda ölçeğin güvenilir olduğu ifade edilmektedir (Durmuş vd., 2011).

Örgütsel Yenilik Ölçeği: Örgütsel Yenilik Ölçeği, Ellonen, Blomqvist ve Puumalainen (2008) tarafından geliştirilmiş ve Timuroğlu (2015) tarafından Türkçe'ye çevrilmiş ve uygulanmıştır. Ölçek toplam 8 ifadeden oluşmaktadır (Örnek İfade: İşletmemizde çalışanlar yeni metotlar kullanma ve yenilikçi çözümler yaratmaya isteklidir). Ölçeğin güvenilirlik katsayısı Alpha $=0,87$ olarak belirlenmiştir.

\section{Bulgular ve Tartışma}

\section{Tanımlayıcı İstatistikler ve Korelasyon Analizi}

Araştırmaya konu olan değişkenlere ilişkin genel aritmetik ortalamalara bakıldığında, konaklama işletmelerinin kurumsallaşma düzeylerinin belirleyicisi olan nesnellik/ tarafsızlık $(x=3,7)$, şeffaflık $(x=3,4)$, formalleşme/ profesyonelleşme $(x=3,4)$ boyutlarının ölçek orta değer olan 3 (orta derecede katılıyorum) noktasının üzerinde sonuç verdiği görülmektedir. Örgütsel yenilik seviyesi de $(x=3,6)$ benzer biçimde, ölçek orta değerinin üzerinde bir ortalamaya sahiptir. Tablo 1'den de görüleceği üzere konaklama işletmelerinin kurumsallaşma düzeyleri yüksek olup, işletmeler en fazla nesnellik ve tarafsızlık açısından kurumsallaşmışlardır.

Değişkenler arasındaki karşılıklı korelasyon katsayıları (r) incelendiğinde, bütün değişkenler arasında 0,01 düzeyinde anlamlılığa sahip, pozitif yönlü, orta veya yüksek düzeyde anlamlı ilişkiler belirlenmiştir. Bu doğrultuda, kurumsallaşmayı oluşturan üç boyutun birbiri ile olan ilişki katsayıları orta düzeyde ve anlamlıdır. Nesnellik/tarafsızlık ile Şeffaflık $(r=0,55$; $\mathrm{p}<, 01)$, Nesnellik/tarafsızlık ile formalleşme/profesyonelleşme $(\mathrm{r}=0,44 ; \mathrm{p}<, 01)$ ve şeffaflık ile formalleşme ve profesyonelleşme $(r=0,67 ; p<, 01)$ arasında orta düzeyde, anlamlı ve pozitif yönlü ilişki vardır.

Tablo 1: Aritmetik Ortalamalar, Standart Sapmalar ve Korelasyon Katsayıları 


\begin{tabular}{|l|l|l|l|l|l|l|}
\hline Değişkenler & A.O. & ST.D. & $\mathbf{1}$ & $\mathbf{2}$ & $\mathbf{3}$ & $\mathbf{4}$ \\
\hline Nesnellik/Tarafsıllı (1) & 3,7 & 0,49 & 1 & & & \\
\hline Şeffaflık (2) & 3,4 & 0,52 &, $55^{* *}$ & 1 & & \\
\hline Formalleşme/Profesyonellik (3) & 3,4 & 0,57 &, $44^{* *}$ &, $67^{* *}$ & 1 & \\
\hline Örgütsel Yenilik (4) & 3,6 & 0,47 &, $43^{* *}$ &, $50^{* *}$ &, $75^{* *}$ & 1 \\
\hline
\end{tabular}

Araştırmanın asıl sorunsalı olan, kurumsallaşmayı oluşturan boyutlar ile örgütsel yenilik arasında ise benzer biçimde pozitif ve anlamlı ilişkiler tespit edilmiştir. Örgütsel yenilik ile nesnellik/tarafsılık $(\mathrm{r}=0,43 ; \mathrm{p}<, 01)$ ve şeffaflık $(\mathrm{r}=0,5 ; \mathrm{p}<, 01)$ arasında orta düzeyde anlamlı bir ilişki vardır. Örgütsel yeniliğin kurumsallaşmanın anahtar unsurlarından biri olan formalleşme ve profesyonelleşme boyutu ile olan ilişkisi ise $(r=0,75 ; \mathrm{p}<, 01)$ güçlü ve pozitif yönlüdür. Elde edilen bulgular kurumsallaşma ile örgütsel yenilik arasında çeşitli düzeylerde anlamlı bir etkileşimin varlığına işaret etmektedir.

\section{Regresyon Analizi ve Hipotez Testleri}

Araştırmaya dâhil olan konaklama işletmelerinde, örgütsel yeniliğe etki eden kurumsallaşma unsurlarını test edebilmek amacıyla kurumsallaşmanın üç boyutunun bağımsız, örgütsel yenilik yöneliminin ise bağımlı değişken olduğu çoklu regresyon analizi gerçekleştirilmiştir (Bkz: Tablo 2).

Tablo 2: Çoklu Regresyon Analizi Bulguları

\begin{tabular}{|l|l|l|l|l|l|l|}
\hline $\begin{array}{l}\text { Bağımlı } \\
\text { Değişken }\end{array}$ & $\begin{array}{l}\text { Bağımsız } \\
\text { Değişkenler }\end{array}$ & BETA & T & SíG. (P) & F & $\mathbf{R}^{2}$ \\
\hline \multirow{3}{*}{$\begin{array}{l}\text { Örgütsel } \\
\text { Yenilik }\end{array}$} & $\begin{array}{l}\text { Nesnellik/ } \\
\text { Tarafsızlık }\end{array}$ & 0,134 & 1,48 & 0,14 & \multirow{2}{*}{33,66} & $0,56^{* *}$ \\
\cline { 2 - 5 } & Şeffaflık & $-0,05$ & $-0,464$ & 0,64 & & \\
\cline { 2 - 5 } & $\begin{array}{l}\text { Formalleşme/ } \\
\text { Profesyonelleşme }\end{array}$ & 0,719 & 7,098 & $0,00^{* *}$ & & \\
\hline
\end{tabular}

Konaklama işletmelerinde örgütsel yenilik düzeyinin açıklanmasında, kurumsallaşmayı oluşturan unsurların etkisini gösteren çoklu regresyon analizi sonuçları incelendiğinde, kurumsallaşma unsurlarının örgütsel yenilik üzerindeki değişimin $\% 56$ 'sını $\left(F=33,66, \mathrm{R}^{2=} 0,56\right)$ açıkladığı görülmektedir. Ancak, çoklu regresyon analizi sonucu kurumsallaşmayı oluşturan unsurlara ilişkin elde edilen $p$ değerlerine bakıldığında, nesnellik/tarafsızlık $(t=1,48$, $\mathrm{p}=0,000>0.001)$ ile şeffaflık $(\mathrm{t}=-0,464, \mathrm{p}=0,000>0.001)$ boyutlarının örgütsel yeniliğin açıklanmasında herhangi bir anlamlı etkisi tespit edilmemiştir. Bu durumun aksine, araştırmaya dahil olan konaklama işletmelerinde kurumsallaşmanın kilit unsurlarından olan formalleşme ve profesyonelleşme eğilimi $(t=7,098, p=0,000<0.001)$, örgütsel yeniliği pozitif yönde ve yüksek anlamlılık düzeyinde etkilemektedir. Beta katsayıları incelendiğinde ise işletmelerde mevcut formalleşme ve profesyonelleşme eğilimlerinin $(\beta=0,72)$ örgütsel yeniliğin gerçekleşmesindeki açıklayıcılığı oldukça yüksektir.

Elde edilen bu sonuç, çalışmanın kavramsal çerçevesinde ifade edilen, örgütsel yenilik yöneliminin oluşmasında ve benimsenmesinde kurumsallaşma unsurlarının etkisinin olabileceği öngörüsü ile kısmen örtüştüğünü göstermektedir. Dolayısıyla, çalışma kapsamında geliştirilen ana hipotez olan $\mathrm{H}_{1}$ hipotezi kısmen kabul edilmiştir. Ana hipotezin kısmen kabul 
edilmesinin nedeni ise, $\mathrm{H}_{1}$ hipotezine bağlı olarak geliştirilen 3 alt hipotezden birinin $\left(\mathrm{H}_{1(3)}\right.$ : Konaklama işletmelerinin formalleşme ve profesyonelleşme yönündeki kurumsallaşma eğilimleri, örgütsel yenilik yönelimlerini pozitif yönde etkiler) istatistiksel olarak anlamlılık göstermesidir. Geri kalan iki alt hipotez ise $\left(\mathrm{H}_{1(1)}\right.$ ve $\left.\mathrm{H}_{1(2)}\right)$ bu araştırma kapsamında reddedilmiştir.

\section{Sonuç ve Öneriler}

Turizm işletmelerinde görev yapan üst düzey yöneticiler üzerinde yapılan anket çalışması sonucunda elde edilen bulgular, konaklama işletmelerinin yeniliklere açık bir anlayışla, sürekli değișen çevre koşullarına uyum göstermelerinde kurumsallaşma eğilimlerinin önemli bir stratejik araç olabileceğini kısmen doğrulamaktadır. Ancak elde edilen ampirik bulgular, işletmelerin belirli konularda üzerinde durması gereken önemli noktalar hakkında da ipucu vermektedir.

Kurumsallaşmayı oluşturan nesnellik, şeffaflık ve formalleşme/ profesyonelleşme boyutlarına ilişkin genel ortalamalar incelendiğinde, en yüksek aritmetik ortalamaya sahip olan unsurun nesnellik olduğu görülmektedir. İşletmelerde çalışanların işe alımından değerlendirilmesine, bilgi paylaşımından ücretlendirmeye kadar tutarlı bir politika izlemesi olarak açıklanabilecek "nesnellik" boyutu, kurumsallaşmanın kilit unsurlarından biridir. İşletmelerde yenilikçi fikirlerin nesnel bir yaklaşım sergilenerek değerlendirilmesi ve geliştirilmesi, yeniliğin örgüt içinde sistematik ve disiplinli bir atmosferde kurumsallaşmasını sağlayacaktır. Yapılan korelasyon analizi sonucunda, nesnellik ile yenilik arasında orta düzeyde güçlü bir ilişkinin varlığı tespit edilmiştir. Ancak nesnelliğin doğrudan örgütsel yenilik üzerinde bir açıklayıcılığı belirlenmemiştir. Bu durum, tutarlılığın veya nesnelliğin, örgütsel yenilik üzerinde doğrudan etkisini tespit eden çalışmaları doğrular nitelikte değildir.

Kurumsallaşmayı meydana getiren diğer iki unsur olan şeffaflık ve formalleşme /profesyonelleşme ise ortalamalar bakımından birbirine benzer sonuçlar vermiştir $(A . O=3,4)$. Ölçek orta değeri olan 3'e yakın görülen bu ortalamalar, konaklama işletmelerinin kurumsallaşması açısından birtakım eksikliklerini gözler önüne sermektedir. Araştırmaya katılan işletme yöneticilerinin şeffaflaşma yönündeki eğilimleri ile örgütsel yenilik yönelimleri arasında, nesnellikte olduğu gibi, orta düzeyde güçlü bir ilişki tespit edilmiştir. Fakat yine nesnellik gibi şeffaflık boyutu da örgütsel yeniliği doğrudan açıklayan bir değişken değildir. İşletmelerde kurumsal düzenin ve yenilikçi anlayışın devamlılığını ve gelişimini sağlamak açısından önemli bir araç olabilecek şeffaflaşmanın, ortalama değerinin işletmelerde düşük olması bu sonucu doğurmuş olabilir. Aynı zamanda, şeffaflığın yenilik üzerindeki olası dolaylı etkilerini konu alan çalışmalar da, iki değişken arasındaki dolaylı ilişkilerin tespiti açısından, yapilabilir.

Kurumsallaşmanın anahtar bileşenlerinden biri olan formalleşme/ profesyonelleşme ise, örgütsel yeniliğe doğrudan etkide bulunan bir değişkendir. korelasyon analizi sonucu iki değişken arasında hem güçlü bir ilişkinin varlığı hem de yüksek düzeyde bir etkileşim belirlenmiştir. Elde edilen bu ampirik bulgular, iki değişken arasındaki etkileşimi tespit eden diğer nicel çalışmalar ile benzer sonuçlar vermektedir. Dolayısıyla, yöneticilerin profesyonel bir anlayış çerçevesinde görevlerini yapmaları ve formalleşmenin getirdiği örgüt yapısından taviz vermemeleri, örgütsel yeniliğin kurumsal bir işleyiş kazanmasını sağlayabilecektir.

Sonuç olarak, Türkiye'de turizm işletmelerinin işleyişinde "patron şirketi” anlayışının sürmekte olduğu ve bu nedenle kurumsallaşma yönünden işletmelerin gerilerde olduğu iddia edilmektedir (Yetim, 2014). Kurumsallaşma sorununun özellikle aile işletmelerinde ortaya çıktığ 1 ve Türkiye' de turizm sektöründe yer alan Dedeman, Hilton, Güral gibi işletmelerin de birer aile işletmesi olduğu bilinen bir gerçektir. Aile işletmelerinde eğitimi deneyimi yeterli olmayan kişiler çalışabilmekte ve kurum kültürüne sahip olmayan işletme yapıları ortaya 
çıkabilmektedir (Yağcı ve Çevirgen, 2015, s. 1252). Bu nedenle işletme yöneticilerinin kurumsallaşma süreçlerini yeniden gözden geçirmeleri ve süreci etkileyen olumsuz etkenleri minimize etmeleri önerilmektedir. Kurumsallaşan işletmelerde etkin bir örgüt yapısı, yetki devri, karar verme şekli, iletişim sistemi (Koç ve Yazıcıoğlu, 2009, s. 500) ile birlikte gelişmiş bir örgüt kültürü ve insana bakış açısı, sistematik eğitim ve geliştirme faaliyetleri, faaliyetlerin belli bir plan ve politikalar içinde gerçekleştirilmesi, yönetimin profesyonelleşmesi gibi sonuçlar gözlemlenir (Çakıcı ve Özer, 2007). Kurumsallaşmanın sağladığı tüm bu avantajlar, işletmelerin yeniliğe gitme yönünde sağlam adımlar atmalarını sağlayacaktır.

$\mathrm{Bu}$ çalışma sonucu, kurumsallaşma-yenilik etkileşimi çerçevesinde turizm sektörü baz alınarak gerçekleştirilen çok az sayıda bilimsel çalışmaya, bir yenisi daha eklenmiştir. Belirlenen araştırma konusunun daha geniş bir teorik çerçeve baz alınarak, farklı değişkenleri araştırmaya dahil ederek ve/veya daha geniş bir örneklem kütlesine ulaşılarak detaylandırılması ve genişletilmesi önerilmektedir.

\section{Kaynakça}

Ak, G. (2010). Aile İşletmelerinde Kurumsallaşmanın İşletme Başarısına Olan Etkileri: Aydın İlinde Faaliyet Gösteren Aile İşletmeleri Örneği. (Yayınlanmamış Doktora Tezi). Aydın: Adnan Menderes Üniversitesi Sosyal Bilimler Enstitüsü.

Aksoy, B. (2007). Bir Meslek Örgütünün Kurumsal Değişimdeki Yeri: Türkiye Sağlık Alanı Örneği. (Yayınlanmamış Doktora Tezi). Ankara: Başkent Üniversitesi Sosyal Bilimler Enstitüsü.

Aktan C., Vural İ. (2004). Rekabet Gücü ve Rekabet Stratejileri, Türkiye İşveren Sendikaları Konfederasyonu, Aralık.

Alpay, G., Bodur, M., Yılmaz, C., Çetinkaya, S. ve Arıkan, L. (2008). Performance implications of institutionalization process in familyownrd businesses: Evidence from an emerging economy. Journal of World Business, 43: 435-448.

Altun, Ş. (2008). A dan Zee Türkiye $Z^{e e} d e n$ İnovasyon Manzaraları. İstanbul. Doğuş İletişim Yayınc1lik. 6-7.

Altunışık, R., Coşkun, R., Bayraktaroğlu, S. ve Yıldırım, E. (2007). Sosyal Bilimlerde Araştırma Yöntemleri SPSS Uygulamalı. Sakarya. Sakarya Yayıncılık.

Antoncic, B. Hisrich, R. D. (2001), Intrapreneurship: Construct Refinement and Cross-Cultural Validation; Journal of Business Venturing, 16: 497-527.

Apaydın, F. (2008), "Kurumsallaşmanın Küçük ve Orta Ölçekli İşletmelerin Performansına Etkileri”, ZKÜ Sosyal Bilimler Dergisi, 4(7): 121-145.

Aşan, C. (2010). Aile Şirketlerinin Performansında Kurumsallaşmanın ve Kültürün Etkisi, Yayımlanmamış Yüksek Lisans Tezi), İstanbul: Kadir Has Üniversitesi Sosyal Bilimler Enstitüsü.

Avermaete, T., Jacques, V., Eleanour, M.,, Nick, C. (2003). "Determinants of Innovation in Small Food Firms", European Journal of Innovation Management, 6(1): 8-17.

Avcı, U. (2009). Öğrenme Yönelimliliğin Yenilik Performansı Üzerine Etkisi: Muğla Mermer Sektöründe Bir İnceleme, ZKÜ Sosyal Bilimler Dergisi, 5(10): 121-138.

Baltalar H. (2012). Küçük ve Orta Büyüklükteki Girişim İstatistikleri Erişim tarihi: 2 Aralık 2015, http://www.hasanbaltalar.com/index.

Bennett, J.V. ve Thompson, H.C. (2011). ChangingPrioritiesfor School-Business Collaboration: Superiatendent Agency and Capacity for Institutionalization. Educational Administration Quartely. 47(5): 826-868.

Bilgin, N. (2007). Aile Şirketleri Kurumsallaşma Eğilimleri: Ankara Kobi Örneği. (Yayınlanmamış Yüksek Lisans Tezi). Ankara: Atılım Üniversitesi Sosyal Bilimler Enstitüsü. 
Bozbayındır, F. (2014). Türkiye'de Yeni Kurulan Kamu Üniversitelerindeki Kurumsallaşmanın İncelenmesi. (Yayınlanmamış Doktora Tezi). Gaziantep Üniversitesi Eğitim Bilimleri Enstitüsü.

Çakıcı, A. Ozer, B. (2007). "Mersin'de Faaliyet Gösteren Küçük Ve Orta Ölçekli İşletmelerin Kurumsallaşma Göstergeleri Açısından İncelenmesi” Balıkesir Üniversitesi Sosyal Bilimler Enstitüsü Dergisi 10(12): 91-92.

Damanpour, F. (1991), Organizational Innovation: A Meta-Analysis of Effects of Determinants and Moderators, Academy of Management Journal, Cilt: 34 (3): 555-590.

Durmuş, Beril, E. Serra Yurtkuru ve Murat Çinko (2011), Sosyal Bilimlerde SPSS'le Veri Analizi, İstanbul: Beta Yayıncilık.

Elçi, Ş. (2007). İnovasyon: Nedir, Ne Değildir?, (Erişim tarihi: 7 Aralık 2015), http://www.kobifinans. com.tr/bilgi_merkezi/021901/6573.

Elçi, Ş. (2009). Rekabet ve kalkınma için inovasyon. MÜSİAD Çerçeve Dergisi, 52, 62-68. Erişim tarihi: 07 Aralık 2015, www.musiad.org.tr/ img/yayinlarraporlar/ cercevedergisi_52_23.pdf.

Ellonen, R., Blomqvist, K. ve Puumalainen, K. (2008). "The Role of Trust in Organizational Innovativeness". European Journal of Innovation Management, 11(2): 160181.

Gökçe, G.S. (2010). İnovasyon Kavramı ve İnovasyonun Önemi. Fırat Kalkınma Ajansı, www.fka.org.tr, Erişim: 03 Aralık 2015.

Karpuzoğlu, E. (2001). Büyüyen ve Gelişen Aile Şirketlerinde Kurumsallaşma. İstanbul. Hayat Yayıncilik.

Keskin, Halit (2006), "Market Orientation, Learning Orientation, and Innovation Capabilities in SMEs", European Journal of Innovation Management, 9(4): 396-417.

Kimberly, J. R. (1979), "Issues in theCreation of Organizations: Initiation, Innovation, Institutionalization," Academy of Management Journal, 19(9): 437-457.

Kiracı, M. ve Alkara, İ. (2009). Aile İşletmelerinde Kurumsallaşmaya Verilen Önem ve Turizm Sektöründeki Konaklama İşletmeleri Üzerine Bir Araştırma: Alanya-Eskişehir Örneği, Afyon Kocatepe Üniversitesi İ.̇̇.B.F. Dergisi, 11(1): 167-197.

Kostova, Tatiana, Kendall Roth ve M.Tina Dacin (2008), "Institutional Theory in the Study of Multinational Corporations: A Critique and New Directions", Academy of Management Review, 33(4): 994-1006.

Meşe, B. (2005), Aile Şirketlerinin Kurumsallaşması, (Yayınlanmamış Yüksek Lisans Tezi). Gebze Yüksek Teknoloji Enstitüsü Sosyal Bilimler Enstitüsü.

Meyer, J. ve Rowan, B. (1997). İnstitutionalized Organizations: FormalStructure as Mythand Ceremony. AmericanJournal Of Sociology. 83(2): 340-363.

OECD (Organization for Economic Co-operation and Development), Avrupa Birliği. (2006). Oslo Kılavuzu: Yenilik Verilerinin Toplanması ve Yorumlanması İçin İlkeler (Çev. TÜBİTAK). (3. Bask1). Ankara: OECD ve Eurostat Ortak Yayını. Erişim tarihi: 7 Aralık 2015. http://www.tubitak.gov.tr/home.do?sid=471\&pid=468.

Peters, Thomas J., Waterman, Robert H. (1982), In Search of Excellence: Lesson from America's Best-Run Companies, Harper Row, New York. Erişim tarihi: 7 Aralık 2015, http://www.readcube.com/articles .

Ruekert, R. W., O. C. Walker, Jr. ve K. J. Roering (1985), "The Organization of Marketing Activities: A Contingency Theory of Structure and Performance", Journal of Marketing, 49(1): $13-25$.

Sabuncu B. (2014). KOBİ'lerde Yenilik ve Engellerinin Tespitine Yönelik Bir Araştırma:Denizli Örneği İşletme Araştırmaları Dergisi 6(1): 103-123.

Schermerhon, John, R. (2007), Exploring Management in Modules, John Wiley, USA. 
Selznick, P. (1996). İnstitutionalizm Old and New. Administrative Science Quartely. 41(2): 270-277.

Scott, W.R. (1995). Institutions and Organizations for Organizational Science. Sage Publications. London.

Tavşancı, S. (2009). Firmalardaki Kurumsallaşma Düzeyinin Rekabet Gücüne Etkisi Üzerine Bir Araştırma (Yayınlanmamış Doktora Tezi). İzmir: Dokuz Eylül Üniversitesi Sosyal Bilimler Enstitüsü.

Timuroğlu K.M. (2015), "Örgütsel ve Çevresel Faktörlerin Örgütsel Yenilik Üzerine Etkisi", Atatürk Üniversitesi Sosyal Bilimler Enstitüsü Dergisi, 19(1): 41-68.

Yağcı E. Ve Çevirgen A. (2015). Kurumsallaşma Düzeyi ve İşletme Yapısı Arasındaki İlişki: Türkiye'deki Beş Yıldızlı Otel İşletmelerinde Bir Uygulama, 15. Ulusal Turizm Kongresi.

Yalçınkaya, Y. (2010). "Bilginin Farkındalık ve Farklılığında Organizasyonların Gelecek Alanı: İnovasyon", Türk Kütüphaneciliği, 24(3): 382-383.

Yazıcıŏlu İ., ve Koç, H. (2009). "Aile İşletmelerinin Kurumsallaşma Düzeylerinin Belirlenmesine Yönelik Karşılaştırmalı Bir Araştırma." Selçuk Üniversitesi Sosyal Bilimler Enstitüsü Dergisi, 21, 502.

Yetim (2014). Turizmde Kurumsallaşma. (Erişim tarihi: 5 Aralık 2015), http://www.turizmguncel. com/makale/turizmde-kurumsallasma-m1291.html.

Yılmaz, Y., (2007). İşletmelerde Kurumsallaşmanın Yenilik ve Performansa Etkisi (Yüksek Lisans Tezi). Gebze Yüksek Teknoloji Enstitüsü.

Yilmaz, C.; Alpkan, L. ve Ergun, E. (2005). Cultural determinants of customer-and learningoriented value systems and their joint effects on firm performance. Journal of Business Research, 58: 1340-1352.

Wallece, J. E. (1995). Organizationaland Professional Commitment in Professional and Nonprofessional Organizations Administrative Science Quarterly, 40(2): 228-255.

Warner, M. J.; Pyle, L. K. (1998). Çabuk İyileşmek İçin, Executive Excellence, Kasım, 2(20): 21-22.

Westphal, J. D., Gulati, R. and Shortell, (1997), "Customization or Conformity? An Institutional and Network Perspective on the Content and Consequences of TQM Adoption", Administrative Science Quarterly, 42: 366-394. 